\title{
EFFECT OF LONG LASTING TERGURIDE TREATMENT ON MUTUAL RELATIONSHIP BETWEEN GLYCIDE AND LIPID PARAMETERS IN SHR/N-cp KOLETSKY RATS
}

\author{
Věroslav Golda ${ }^{1}$, Jiřina Hilgertová ${ }^{2}$ \\ Institute of Experimental Neurosurgery, Charles University, Faculty of Medicine and Teaching Hospital, Hradec Králové ${ }^{\prime}$; \\ (Head: doc. MUDr. J. Náhlovský, CSc.) \\ Laboratory for Endocrinology and Metabolism, Charles University, Faculty of Medicine, Prague²; \\ (Head: prof. MUDr. V. Schreiber, DrSc.)
}

\begin{abstract}
Summary: Experiments were performed in the genetically hypertensive obese rats of Koletsky type (SHR/N-cp) and in their lean siblings. The effect of long lasting terguride treatment on glycide and lipid metabolism was monitored.Terguride decreases insulinemia in all groups of rats. In all groups of rats terguride increases tolerance glucose.Terguride increases insulin binding to erythrocytes in all groups of rats except SHR/N-cp obese females.The mentioned drug decreases plasma triglycerides in SHR/N-cp obese females. On the other hand, this drug increases plasma triglycerides in SHR/N-cp obese males. Correlation between basal glycemia and insulin binding to erythrocytes as well as between triglycerides and insulinemia which was found in control SHR/N-cp lean males is missing under the terguride treatment. Similarly, correlation between plasma triglycerides and insulinemia, glucose tolerance and insulinemia,basal glycemia and insulinemia,plasma triglycerides and basal glycemia are missing under the terguride treatment in SHR/N-cp lean females.Under the terguride treatment there appears correlation between insulin binding to erythrocytes and basal glycemia. We found in SHR/N-cp obese males opposite changes in number of correlations when we compare control and terguride animals. While in controls only one correlation was detected, i.e.,correlation between glucose tolerance and insulin binding to erythrocytes, then under the terguride treatment there appear correlations when basal glycemia is computed versus insulin binding to erythrocytes or to glucose tolerance and/or to triglycerides. Moreover, there is under the terguride treatment correlation insulin binding to erythrocytes versus plasma triglycerides or versus insulinemia. While in SHR/N-cp lean of both sexes and in SHR/N-cp obese males profound changes in the number of statistically significant correlation coefficients were found when controls are compared with animals under the terguride treatment, the different picture we found in SHR/N-cp obese females,i.e.,under the terguride treatment correlation basal glycemia versus insulinemia or versus insulin binding to erythrocytes as well as correlation insulin binding to erythrocytes versus insulinemia is present in controls as well as in terguride treated animals. In comparison with controls under terguride only two correlations are missing, i.e., glucose tolerance versus insulinemia or versus insulin binding to erythrocytes.
\end{abstract}

Key words: Triglycerides; Glucose tolerance; Insulinemia; Insulin binding to erythrocytes; Glycemia; Triglycerides; Correlations between glycide and lipid metabolism

\section{Introduction}

The proper aim of our experiments is looking for the type of animals where dopaminergic agonist terguride is potent not only to alleviate hypertriglyceridemia but it is potent to alleviate glucose intolerance based genetically. Both abnormalities are maximally expressed in SHR/N-cp obese rats of Koletsky type (2). While glucose intolerance is alleviated in both sexes of obese rats in the same manner then hypertriglyceridemia is significantly decreased by long lasting terguride treatment only in SHR/N-cp obese females
$(2,4)$. When regression analysis was performed in SHR/Nobese and in their lean siblings (4) and where plasma triglycerides were used as a dependent variable and plasma insulin, insulin binding to erythrocytes, basal plasma glucose and glucose tolerance data were used as independent variables the SHR/N-cp obese females represent the exception. In the control animals insulinemia was found to be dominant independent variable in all groups except SHR/N-cp obese females where the dominant independent variable was represented by the basal glycemia. Under the terguride treatment only in SHR/N-cp obese female rats the 
dominant independent variable remained the same as in controls. In the other groups under the terguride treatment the dominant independent variable was different in relation to the control. Thus when we are using a multiple regression analysis as tool for detection of the role of independent variables in the determination of dependent variable, i.e., plasma triglycerides, then SHR/N-cp obese females represent the exception when the dominant independent variable in the control animals as well as in the animals under the long lasting terguride treatment is taken into consideration.

The mentioned exception is accompanied by the other exception, i.e., terguride is potent to decrease plasma triglycerides only in SHR/N-cp obese females.

In the present study we are looking for a possible pendat to the above mentioned findings. As a tool we are again using correlation computation.

\section{Material and Methods}

\section{Animals}

Experiments were performed in obese and lean genetically hypertensive rats of Koletsky type (6) of both sexes. Lean SHR/N-cp rats represent dominat non-obese homozygotes and heterozygotes whereas their obese siblings are recessive homozygotes (cp/cp). The abnormal animals were obtained by Koletsky (6) when mating spontaneously hypertensive rat (Okamoto-Aoki strain) with a normotensive Sprague-Dawley male rat. The genetically obese animals appeared after several generations of selective inbreeding of hypertensive off-springs of the original cross.

The blood pressure (measured by an indirect method) attained in lean genetically hypertensive SHR/N-cp males $24.61+2.22 \mathrm{kPa}(\mathrm{n}=15), 17.60+1.32 \mathrm{kPa}(\mathrm{n} \% 8)$ in females (1). The obese genetically hypertensive SHR/N-cp rats show comparable blood pressure (6).

After weaning at the age of 30 days the animals were kept in groups of four and supplied with water and DOS-2b pelleted diet ad libitum. During the experiments the animals were kept in group of two. Body weight, water and pellet intake were controlled daily (except Saturday and Sunday).

\section{Plasma insulin}

Plasma insulin was estimated by radioimmunoassay.

\section{Insulin binding to erythrocytes}

Plasma was separated from approximately $3 \mathrm{ml}$ of heparinized blood drawn by cardiac puncture. Erythrocytes were obtained in the presence of constant amount of ${ }^{125} \mathrm{I}$ insulin $(33 \mathrm{pM})$ at $15{ }^{0} \mathrm{C} 3$ hours. Results were corrected for nonspecific bindings. The details of the method were published previously (5).

\section{Plasma lipids}

Blood sampled by cardiac puncture (in ether anaesthesia at 07.00 after $14 \mathrm{~h}$ starvation) was centrifugated and the serum was stored in plastic tubes at $-20^{\circ} \mathrm{C}$. Total plasma cholesterol and plasma triglycerides were estimated enzymatically by Hitachi analyzer.

\section{Glucose tolerance}

Blood was sampled to heparinized capillaries from retrobulbar plexus under light ether anaesthesia before glucose loading (basal glycemia) as well as $30,60,120$ and 180 min after glucose loading. Under the term „light ether anaesthesia" we understand that individual samplings were finished up to about seventy min after the beiginning of etherization. Glucose (3g/kg b.w., 30\% solution) was applied intragastrically after $14 \mathrm{~h}$ starvation. Glycemia was estimated enzymatically (Oxochrom glucose, Lachema). Glucose tolerance is expressed as a sum of glycemia obtained 30,60,120 and 180 min after glucose loading (,area under the glucose tolerance curve“).

\section{Terguride treatment}

The drug was applied i.p. in two daily doses ( 07.00 and 14.00) for 21 days (when lipemia was investigated) or for 11 days only (when glucose tolerance was monitored). Terguride maleate was administered at a dose of $0.1 \mathrm{mg} / \mathrm{kg}$ b.w.

\section{Statistics}

The data were analyzed by the Student t-test. Correlation coefficients were computed when Spearman (nonparametric) and Pearson (parametric) tests were used.For computation of t-test as well as correlation coefficient program SOLO were used.

\section{Results}

SHR/N-cp lean males (see Table 2 and 3)

In control animals statistically significant correlation coefficient was attained by parametric Pearson test when basal glycemia was computed versus insulin binding to erythrocytes and plasma triglycerides versus insulinemia.

Statistical significance of both correlation coefficients is missing under the long lasting terguride treatment.

Table l: Effect of long term terguride treatment on the analyzed variables

\begin{tabular}{|c|c|c|c|c|c|}
\hline variables & drug & SHR-M & SHR-F & SHR-O-M & SHR-O-F \\
\hline $\begin{array}{l}\text { insulinemia } \\
(\mathrm{pmol} / \mathrm{l})\end{array}$ & $\begin{array}{l}\mathrm{Co} \\
\mathrm{Te}\end{array}$ & \begin{tabular}{|l|}
$243+77(7)$ \\
$179+49(8)^{\mathrm{b}}$ \\
\end{tabular} & $\begin{array}{l}202+68(8) \\
169+21(8)^{\mathrm{a}}\end{array}$ & \begin{tabular}{|l|}
$861+452(13)$ \\
$598+212(15)^{\mathrm{d}}$ \\
\end{tabular} & $\begin{array}{l}521+289(14) \\
399+190(11)^{\mathrm{d}}\end{array}$ \\
\hline $\begin{array}{l}\text { insulin binding } \\
\text { to erythrocytes }\end{array}$ & $\begin{array}{l}\mathrm{Co} \\
\mathrm{Te}\end{array}$ & $\begin{array}{l}2.1+0.9(7) \\
3.2+0.7(8)^{\mathrm{d}}\end{array}$ & $\begin{array}{l}1.9+0.6(7) \\
2.7+0.6(7)^{d}\end{array}$ & \begin{tabular}{|l|}
$3.7+2.5(13)$ \\
$10.3+7.1(15)^{\mathrm{d}}$
\end{tabular} & $\begin{array}{l}2.7+1.7(14) \\
3.1+1.8(11)\end{array}$ \\
\hline $\begin{array}{l}\text { triglycerides } \\
(\mathrm{mmol} / \mathrm{l})\end{array}$ & $\begin{array}{l}\mathrm{Co} \\
\mathrm{Te}\end{array}$ & \begin{tabular}{|l|}
$0.9+0.2(7)$ \\
$0.9+0.2(8)$
\end{tabular} & $\begin{array}{l}1.0+0.4(8) \\
0.8+0.2(8)\end{array}$ & $\begin{array}{l}3.2+1.3(13) \\
5.7+4.2(15)^{\mathrm{c}}\end{array}$ & $\begin{array}{l}4.0+1.1(14) \\
2.9+0.5(11)^{\mathrm{d}}\end{array}$ \\
\hline $\begin{array}{l}\text { glucose } \\
\text { tolerance } \\
\mathrm{mmol} / 1\end{array}$ & $\begin{array}{l}\mathrm{Co} \\
\mathrm{Te}\end{array}$ & $\begin{array}{l}533+39(7) \\
484+52(7)^{\mathrm{b}}\end{array}$ & $\begin{array}{l}543+61(7) \\
492+33(8)^{\mathrm{c}}\end{array}$ & $\begin{array}{l}753+198(13) \\
528+43(12)^{\mathrm{d}}\end{array}$ & $\begin{array}{l}647+144(13) \\
446+48(48)^{d}\end{array}$ \\
\hline $\begin{array}{l}\text { basal final } \\
\text { glycemia } \\
\mathrm{mmol} / 1\end{array}$ & $\begin{array}{l}\mathrm{Co} \\
\mathrm{Te}\end{array}$ & $\begin{array}{l}6.5+0.4(7) \\
6.2+0.8(8)\end{array}$ & $\begin{array}{l}5.5+1.1(8) \\
5.7+1.0(8)\end{array}$ & $\begin{array}{l}7.3+3.1(13) \\
6.4+1.412)\end{array}$ & $\begin{array}{l}6.2+0.7(13) \\
6.1+1.812)\end{array}$ \\
\hline
\end{tabular}

Table 1: Mean and standard deviation of the individual parameters. Abbreviations:SHR:genetically hypertensive rats of Koletsky (SHRN/-cp lean), SHR-O: genetically hypertensive obese rats of Koletsky type (SHR/N-cp obese). M - males, F - females.Statistical significan ce: $\mathrm{a}=\mathrm{P}<0.10, \mathrm{~b}=\mathrm{P}<0.05, \mathrm{c}=\mathrm{P}<0.02, \mathrm{~d}=\mathrm{P}<0.01$. $\mathrm{Co}=$ control animals, Te animals unde the long term terguride treatment. Number in bracketts = number of animals per group 
Table 2: Control SHR/N-cp lean males:correlation coefficients

\begin{tabular}{|l|c|c|c|c|c|c|}
\hline $\mathrm{n}=7$ & test & $\begin{array}{c}\text { glycemia } \\
\text { basal }\end{array}$ & $\begin{array}{c}\text { insulin } \\
\text { binding }\end{array}$ & $\begin{array}{c}\text { glucose } \\
\text { toler }\end{array}$ & $\begin{array}{c}\text { insuli- } \\
\text { nemia }\end{array}$ & $\begin{array}{c}\text { trigly- } \\
\text { cerides }\end{array}$ \\
\hline basal & $\mathrm{S}$ & - & -0.6301 & -0.4818 & +0.07413 & +0.4818 \\
glycaemia & $\mathrm{P}$ & - & $-0.7933^{\mathrm{b}}$ & -0.4713 & +0.0507 & +0.3941 \\
\hline insulin & $\mathrm{S}$ & - & - & +0.4286 & -0.3215 & -0.4643 \\
binding & $\mathrm{P}$ & - & - & +0.5204 & -0.3606 & -0.5665 \\
\hline glucose & $\mathrm{S}$ & - & - & - & -0.3929 & -0.2500 \\
toler. & $\mathrm{P}$ & - & - & - & -0.4421 & -0.2120 \\
\hline insuli- & $\mathrm{S}$ & - & - & - & - & $+0.6429^{\mathrm{a}}$ \\
nemia & $\mathrm{P}$ & - & - & - & - & $+0.7277^{\mathrm{a}}$ \\
\hline
\end{tabular}

Table 2. Correlation coefficients. Abbreviations: S - Spearman nonparametric correlation, $\mathrm{P}$ - Pearson parametric correlation. $\mathrm{n}=$ number of rats in analyzed group. The other abbreviations are the same as in Table 1 .

Table 3: Terguride SHR/N-cp lean males: correlation coefficients

\begin{tabular}{|l|c|c|c|c|c|c|}
\hline $\mathrm{n}=8$ & test & $\begin{array}{c}\text { glycemia } \\
\text { basal }\end{array}$ & $\begin{array}{c}\text { insulin } \\
\text { binding }\end{array}$ & $\begin{array}{c}\text { glucose } \\
\text { toler. }\end{array}$ & $\begin{array}{c}\text { insili- } \\
\text { nemia }\end{array}$ & $\begin{array}{c}\text { trigly- } \\
\text { glycerides }\end{array}$ \\
\hline basal & $\mathrm{S}$ & - & +0.0241 & -0.6145 & -0.5202 & 0.0000 \\
glycaemia & $\mathrm{P}$ & - & +0.0462 & -0.5663 & -0.3374 & -0.1070 \\
\hline insulin & $\mathrm{S}$ & - & - & +0.3571 & +0.4047 & +0.0952 \\
binding & $\mathrm{P}$ & - & - & +0.3418 & +0.5950 & +0.1747 \\
\hline glucose & $\mathrm{S}$ & - & - & - & +0.2381 & -0.3095 \\
toler. & $\mathrm{P}$ & - & - & - & +0.4946 & -0.2192 \\
\hline insuli- & $\mathrm{S}$ & - & - & - & - & +0.5714 \\
nemia & $\mathrm{P}$ & - & - & - & - & +0.5727 \\
\hline
\end{tabular}

Table 3. Correlation coefficients. The abbreviations are the same as in Table 1 and 2.

\section{SHR/N-cp lean females (see Table 4 and 5)}

In control animals statistically significant correlation coefficient was attained by parametric Pearson test when basal glycemia was computed versus insulinemia as well as versus plasma triglycerides. At the level of trend $(\mathrm{P}<0.10)$ the significance was attained by parametric Pearson test when insulinemia was computed versus plasma triglycerides as well as versus glucose tolerance.

Under the long lasting terguride treatment we found only one statistically significant correlation coefficient, i.e.,when glycaemia was computed versus insulin binding to erythrocytes by parametric Pearson as well as by nonparametric Spearman test.

Table 4: Control SHR/N-cp lean females: correlation coefficients

\begin{tabular}{|l|c|c|c|c|c|c|}
\hline $\mathrm{n}=8$ & test & $\begin{array}{c}\text { basal } \\
\text { glycemia }\end{array}$ & $\begin{array}{c}\text { insulin } \\
\text { binding }\end{array}$ & $\begin{array}{c}\text { glucose } \\
\text { toler. }\end{array}$ & $\begin{array}{c}\text { insuli- } \\
\text { nemia }\end{array}$ & $\begin{array}{c}\text { trigly- } \\
\text { cerides }\end{array}$ \\
\hline basal & $\mathrm{S}$ & - & -0.0719 & -0.5389 & -0.5030 & -0.7066 \\
glycaemia & $\mathrm{P}$ & - & +0.0586 & -0.5557 & $-0.7996^{\mathrm{c}}$ & $-0.8188^{\mathrm{c}}$ \\
\hline insulin & $\mathrm{S}$ & - & - & -0.3571 & -0.5000 & +0.2143 \\
binding & $\mathrm{P}$ & - & - & -0.5761 & -0.3348 & +0.2352 \\
\hline glucose & $\mathrm{S}$ & - & - & - & +0.2143 & +0.3333 \\
toler. & $\mathrm{P}$ & - & - & - & $+0.6532^{\mathrm{a}}$ & +0.3442 \\
\hline insuli- & $\mathrm{S}$ & - & - & - & - & +0.5476 \\
nemia & $\mathrm{P}$ & - & - & - & - & $+0.6500^{\mathrm{a}}$ \\
\hline
\end{tabular}

Table 4. Correlation coefficients. The abbreviations are the same as in Table 1 and 2.
Table 5: Terguride SHR/N-cp lean females: correlation coefficients

\begin{tabular}{|l|c|c|c|c|c|c|}
\hline $\mathrm{n}=8$ & test & $\begin{array}{c}\text { basal } \\
\text { glycemia }\end{array}$ & $\begin{array}{c}\text { insulin } \\
\text { binding }\end{array}$ & $\begin{array}{c}\text { glucose } \\
\text { toler. }\end{array}$ & $\begin{array}{c}\text { insuli- } \\
\text { nemia }\end{array}$ & $\begin{array}{c}\text { trigly- } \\
\text { cerides }\end{array}$ \\
\hline basal & $\mathrm{S}$ & - & $-0.8333^{\mathrm{c}}$ & -0.3333 & -0.0952 & -0.4286 \\
glycaemia & $\mathrm{P}$ & - & $-0.7818^{\mathrm{b}}$ & -0.1843 & -0.0607 & -0.5504 \\
\hline insulin & $\mathrm{S}$ & - & - & +0.0714 & +0.3095 & +0.4286 \\
binding & $\mathrm{P}$ & - & - & +0.1409 & -0.0353 & +0.2850 \\
\hline glucose & $\mathrm{S}$ & - & - & - & -0.0714 & -0.1667 \\
toler. & $\mathrm{P}$ & - & - & - & +0.2437 & -0.2139 \\
\hline insuli- & $\mathrm{S}$ & - & - & - & - & -0.0238 \\
nemia & $\mathrm{P}$ & - & - & - & - & 0.0579 \\
\hline
\end{tabular}

Table 5. Correlation coefficients. Tha abbreviations are the same as in Table 1 and 2.

\section{SHR/N-cp obese males (see Table 6 and 7)}

In the control animals statistically significant correlation coefficient was attained by parametric Pearson test when glucose tolerance was computed versus insulin binding to erythrocytes. Significance at the level of trend $(\mathrm{P}<0.10)$ was attained also by nonparametric Spearman test.

Under the long lasting terguride treatment the significance was attained by parametric Pearson test when glycemia was computed versus insulin binding to erythrocytes as well as versus triglycerides, and when insulin binding to erythrocytes was computed versus plasma triglycerides. Significance at the level of trend $(\mathrm{P}<0.10)$ was attained by Pearson test when insulinemia was computed versus insulin binding as well as by computation glycemia versus glucose tolerance. When using nonparametric Spearman test significance was attained by computation glycemia versus insulin binding to erythrocytes and significance at the level of trend $(\mathrm{P}<0.10)$ was attained when glycaemia was computed versus triglycerides.

Table 6: Control SHR/N-cp obese males: correlation coefficients

\begin{tabular}{|l|c|c|c|c|c|c|}
\hline $\mathrm{n}=13$ & test & $\begin{array}{c}\text { basal } \\
\text { glycemia }\end{array}$ & $\begin{array}{c}\text { insulin } \\
\text { binding }\end{array}$ & $\begin{array}{c}\text { glucose } \\
\text { toler. }\end{array}$ & $\begin{array}{c}\text { insuli- } \\
\text { nemia }\end{array}$ & $\begin{array}{c}\text { trigly- } \\
\text { cerides }\end{array}$ \\
\hline basal & $\mathrm{S}$ & - & -0.0220 & +0.4231 & +0.3187 & -0.1154 \\
glycaemia & $\mathrm{P}$ & - & +0.1433 & +0.4338 & +0.2182 & -0.2168 \\
\hline insulin & $\mathrm{S}$ & - & - & $+0.5695^{\mathrm{a}}$ & -0.1045 & -0.0110 \\
binding & $\mathrm{P}$ & - & - & $+0.5943^{\mathrm{b}}$ & -0.4891 & -0.2163 \\
\hline glucose & $\mathrm{S}$ & - & - & - & -0.2143 & -0.3516 \\
toler. & $\mathrm{P}$ & - & - & - & -0.1886 & -0.2308 \\
\hline insuli- & $\mathrm{S}$ & - & - & - & - & +0.2308 \\
nemia & $\mathrm{P}$ & - & - & - & - & +0.2609 \\
\hline
\end{tabular}

Table 6. Correlation coefficients. The abbreviations are the same as in Table 1 and 2.

Table 7: Terguride SHR/N-cp obese males: correlation coefficients

\begin{tabular}{|l|c|c|c|c|c|c|}
\hline $\mathrm{n}=12$ & test & $\begin{array}{c}\text { basal } \\
\text { glycemia }\end{array}$ & $\begin{array}{c}\text { insulin } \\
\text { binding }\end{array}$ & $\begin{array}{c}\text { glucose } \\
\text { toler. }\end{array}$ & $\begin{array}{c}\text { insuli- } \\
\text { nemia }\end{array}$ & $\begin{array}{c}\text { trigly- } \\
\text { cerides }\end{array}$ \\
\hline basal & $\mathrm{S}$ & - & $-0.6515^{\mathrm{b}}$ & +0.1748 & +0.4825 & $-0.5594^{\mathrm{a}}$ \\
glycaemia & $\mathrm{P}$ & - & $-0.7249^{\mathrm{d}}$ & $+0.5316^{\mathrm{a}}$ & +0.5698 & $-0.8486^{\mathrm{d}}$ \\
\hline insulin & $\mathrm{S}$ & - & - & -0.1576 & -0.4904 & +0.3152 \\
binding & $\mathrm{P}$ & - & - & -0.3147 & $-0.5246^{\mathrm{a}}$ & $+0.5851^{\mathrm{b}}$ \\
\hline glucose & $\mathrm{S}$ & - & - & - & +0.4895 & -0.2448 \\
tolerance & $\mathrm{P}$ & - & - & - & +0.4736 & -0.4067 \\
\hline insuli- & $\mathrm{S}$ & - & - & - & - & -0.3497 \\
nemia & $\mathrm{P}$ & - & - & - & - & -0.5501 \\
\hline
\end{tabular}

Table 7. The abbreviations are the same as in Table 1 and 2 


\section{SHR/N-cp obese females(see Table 8 and 9)}

In control animals statistically significant correlation coefficient was attained by parametric Pearson test when insulin binding to erythrocytes was computed versus glucose tolerance (the same was attained by nonparametric test) as well as versus insulinemia (the same was attained by nonparametric test). When using nonparametric Spearman test statistically significant correlation coefficient was attained when glycemia was computed versus insulinemia. Significance at the level of trend $(\mathrm{P}<0.10)$ was attained when glycemia versus insulin binding to erythrocyles were computed by parametric test (the same was attained by using nonparametric test) and by computation glucose tolerance versus insulinemia.

Under the long lasting terguride treatment the stastical significance of correlation coefficient remained the same as in the control animals when glycaemia was computed versus insulinemia as well as versus insulin binding, and when glycemia was computed versus insulinemia.

Table 8: Control SHR/N-cp obese females: correlation coefficients

\begin{tabular}{|l|c|c|c|c|c|c|}
\hline $\mathrm{n}=13$ & test & $\begin{array}{c}\text { basal } \\
\text { glycemia }\end{array}$ & $\begin{array}{c}\text { insulin } \\
\text { binding }\end{array}$ & $\begin{array}{c}\text { glucose } \\
\text { toler. }\end{array}$ & $\begin{array}{c}\text { insuli- } \\
\text { nemia }\end{array}$ & $\begin{array}{c}\text { trigly- } \\
\text { cerides }\end{array}$ \\
\hline basal & $\mathrm{S}$ & - & $-0.5055^{\mathrm{a}}$ & -0.1648 & $+0.5604^{\mathrm{b}}$ & +0.0798 \\
glycaemia & $\mathrm{P}$ & - & $-0.5367^{\mathrm{a}}$ & -0.1965 & +0.2803 & +0.0686 \\
\hline insulin & $\mathrm{S}$ & - & - & $+0.5714^{\mathrm{b}}$ & $-0.7912^{\mathrm{d}}$ & -0.1541 \\
binding & $\mathrm{P}$ & - & - & $+0.7205^{\mathrm{c}}$ & $-0.7109^{\mathrm{d}}$ & -0.1091 \\
\hline glucose & $\mathrm{S}$ & - & - & - & -0.4176 & -0.4264 \\
tolerance & $\mathrm{P}$ & - & - & - & $-0.5249^{\mathrm{a}}$ & -0.3298 \\
\hline insuli- & $\mathrm{S}$ & - & - & - & - & +0.2146 \\
nemia & $\mathrm{P}$ & - & - & - & - & +0.23 \\
\hline
\end{tabular}

Table 8. Correlation coefficients. The abbreviations are the same as in Table 1 and 2.

Table 9: Terguride SHR/N-cp obese females: correlation coefficients

\begin{tabular}{|l|c|c|c|c|c|c|}
\hline $\mathrm{n}=12$ & test & $\begin{array}{c}\text { basal } \\
\text { glycemia }\end{array}$ & $\begin{array}{c}\text { insulin } \\
\text { binding }\end{array}$ & $\begin{array}{c}\text { glucose } \\
\text { toler. }\end{array}$ & $\begin{array}{c}\text { insuli- } \\
\text { nemia }\end{array}$ & $\begin{array}{c}\text { trigly- } \\
\text { cerides }\end{array}$ \\
\hline basal & $\mathrm{S}$ & - & $-0.5664^{\mathrm{a}}$ & -0.1818 & $+0.6935^{\mathrm{c}}$ & -0.1608 \\
glycaemia & $\mathrm{P}$ & - & $-0.4988^{\mathrm{a}}$ & -0.1764 & +0.2653 & -0.4129 \\
\hline insulin & $\mathrm{S}$ & - & - & +0.2937 & $-0.8757^{\mathrm{d}}$ & -0.1748 \\
binding & $\mathrm{P}$ & - & - & +0.1572 & $-0.5869^{\mathrm{b}}$ & -0.2085 \\
\hline glucose & $\mathrm{S}$ & - & - & - & -0.2767 & -0.1049 \\
toler. & $\mathrm{P}$ & - & - & - & -0.4730 & -0.2772 \\
\hline insuli- & $\mathrm{S}$ & - & - & - & - & +0.0701 \\
nemia & $\mathrm{P}$ & - & - & - & - & +0.3337 \\
\hline
\end{tabular}

Table 9. Correlation coefficients. Tha abbreviations are the same as in Table 1 and 2.

\section{Discussion}

As mentioned in the introduction proper aim of our previous (4) paper as well as our recent series of experiments is looking for the symptoms which can be used for the prediction of the group of animals and/or possibly of human patients suffering from hypertriglyceridemia which is accompanied by hyperinsulinemia and glucose intolerance and where dopaminergic agonist terguride can be used as a remedy. In our previous paper (2) we documented that SHR/N-cp obese rats of Koletsky type can be considered as a genetically based pathology resembling the Reaven syndrom in human medicine. In our clinical study (3) we found that terguride shows ambivalent effect in the patients suffering from hyperlipemia which is accompanied by glucose intolerance.Terguride alleviated hyperlipemia as well as glucose intolerance only in patients with high hypetriglyceridemia and high level of glucose intolerance. On the other hand, in the patients who show only mild elevation of plasma triglycerides and mild glucose intolerance, terguride treatment remains without effect or there can be found aggraviation.

In recent series of experiments we found ambivalent effect of terguride treatment in SHR/N-cp obese rats. While in the females terguride alleviates the hypertriglyceridemia, then in males hypertriglyceridemia is aggravated (see Table 1). In the present series of experiments the triglyceridemia in SHR/N-cp obese males is lower than in obese females (see Table 1). On the other hand, in our previous paper (2) we found that terguride in SHR/N-cp of both sexes alleviated hypertriglyceridemia. But in these series of experiments the hypertriglyceridemia in control animals was the same in both sexes and in the males it was significantly higher than in the SHR/N-cp males which were monitored in the present series of experiments.

Thus, again the higher hypertriglyceridemia $(4.60 \pm 1.51$ $/ 7 /)(2)$ is alleviated by terguride and the lower $(3.20 \pm 1.30$ /13/)hypertriglyceridemia was aggravated by the mentioned drug ( see Table 1 in the recent series of experiments). To what extent the mentioned data can be judged as an expression of terguride ambivalent effect, it remains to be solved.

Now some words to the group of animals where terguride shows alleviating effect, i.e., to the SHR/N-cp obese females (see Table 1). In our previous paper (4) multiple regression analysis of parameters of lipid and glycide metabolism was analyzed in SHR/N-cp obese as well as lean rats.Regression analysis was performed when plasma triglycerides were used as a dependent variable and plasma insulin, insulin binding to erythrocytes, plasma glucose and glucose tolerance data were used as independent variables. In the control animals insulinemia was found to be dominant independent variable in all groups except SHR/N-cp obese females where the dominat independent variable was represented by the basal plasma glycemia. Under the terguride treatment only in SHR/N-cp female rats the dominant independent variable remained the same as in control animals.In the other group the dominat independent variable was different in relation to the control animals. Thus it can be said that terguride is potent to alleviate hypertriglyceridemia only in animals when under the treatment by the mentioned drug the dominant independent is not changed and remained stable. The mentioned functional stability suggests the stability which was found in the recent series of experiments when the mutual correlations between gly- 
cide and lipid metabolism were analyzed and where only in SHR/N-cp obese females under the terguride treatment the correlation between the parameters of glycide metabolism remained the same as in control animals (see Table 10): glycemia versus insulin binding, insulin binding versus insulinemia, and glycemia versus insulinemia). In the other groups of animals no correlation which was found in control animals remained in animals under the terguride treatment.

Thus it can be concluded that terguride is potent to alleviates hypertriglyceridemia only under the conditions where this drug is without potency to change mutual relationship between the parameters of glycide metabolismus and plasma triglycerides (see the results of multiple regression analysis - /4/) or to change the mutual correlations between the parameters of glycide metabolism (see the Table 10 of the recent paper).

Very interesting findings were obtained in SHR/N-cp obese males. Terguride shows profound elevation of plasma triglycerides in the mentioned group of animals and this elevation is accompanied by very profound increase of the statistically significant correlations between glycide and lipid parameters. On the other hand, the only statistically significant correlation which we found in the control animals is missing under the long lasting terguride treatment.These very important data are worthy of additional analysis.

Table 10: Comparison between the terguride effect on individual parameters and on mutual correlation of the parametres

\begin{tabular}{|c|c|c|c|c|c|}
\hline Group & $\mathrm{n}$ & parar & metres & Spearman & Pearson \\
\hline $\begin{array}{l}\text { SHR-M: } \\
\text { Control lean }\end{array}$ & 7 & $\begin{array}{c}\text { glycemia } \\
\text { triglycerides }\end{array}$ & $\begin{array}{l}\text { / insulin binding } \\
\text { / } \text { insulinemia }^{\mathrm{b}}\end{array}$ & $\begin{array}{l}-0.6301 \\
+0.6429\end{array}$ & $\begin{array}{l}-0.7933^{\circ} \\
+0.7277^{\circ}\end{array}$ \\
\hline $\begin{array}{l}\text { SHR-M: } \\
\text { Tergu lean }\end{array}$ & 8 & - & I & - & - \\
\hline $\begin{array}{l}\text { SHR-F: } \\
\text { Control lean }\end{array}$ & 8 & $\begin{array}{c}\text { triglycerides } \\
\text { glucose tolerance } \\
\text { glycemia } \\
\text { triglycerides }\end{array}$ & $\begin{array}{cc}/ & \text { insulinemia }^{\mathrm{a}} \\
/ & \text { insulinemia }^{\mathrm{a}} \\
/ & \text { insulinemia }^{\mathrm{a}} \\
/ & \text { glycemia }\end{array}$ & $\begin{array}{l}+0.5476 \\
+0.2143 \\
-0.5030 \\
-0.7066^{\mathrm{a}}\end{array}$ & $\begin{array}{l}+0.6500^{\mathrm{a}} \\
+0.6532^{\mathrm{a}} \\
-0.7996^{\mathrm{c}} \\
-0.8188^{\mathrm{c}}\end{array}$ \\
\hline $\begin{array}{l}\text { SHR-F: } \\
\text { Tergu lean }\end{array}$ & 8 & glycemia & / insulin binding ${ }^{\mathrm{d}}$ & $-0.8333^{\mathrm{d}}$ & $-0.7818^{b}$ \\
\hline $\begin{array}{l}\text { SHR-M: obese } \\
\text { Control } 13 \text { (13) }\end{array}$ & & glucose tolerance ${ }^{\mathrm{d}}$ & / insulin binding & $+0.5695^{\mathrm{b}}$ & $+0.5943^{b}$ \\
\hline $\begin{array}{l}\text { SHR-M: } \\
\text { Tergu 12: } \\
(\mathrm{n}=12) \\
\text { obese }\end{array}$ & & $\begin{array}{l}\text { glycemia } \\
\text { insulinemia }^{\mathrm{d}} \\
\text { glycemia } \\
\text { triglycerides }^{\mathrm{c}}\end{array}$ & $\begin{array}{l}\text { / insulin binding }{ }^{\mathrm{d}} \\
\text { / insulin binding }{ }^{\mathrm{d}} \\
\text { /glucose tolerance } \\
\text { / insulin binding }\end{array}$ & $\begin{array}{l}-0.6515^{\mathrm{b}} \\
-0.4904^{\mathrm{a}} \\
+0.1748 \\
+0.3152\end{array}$ & $\begin{array}{l}-0.7249^{\mathrm{d}} \\
-0.5246^{\mathrm{a}} \\
+0.5316^{\mathrm{a}} \\
+0.5881^{\mathrm{b}}\end{array}$ \\
\hline $\begin{array}{l}\text { SHR-F: } \\
\text { Control } 13 \\
\text { obese }\end{array}$ & & $\begin{array}{l}\text { glycemia } \\
\text { glycemia } \\
\text { insulin binding } \\
\text { insulin binding } \\
\text { glucose toler. }^{\mathrm{d}}\end{array}$ & $\begin{array}{lc}\text { / } & \text { insulin binding } \\
/ & \text { insulinemia }^{\mathrm{d}} \\
/ & \text { glucose toler. }^{\mathrm{d}} \\
/ & \text { insulinemia }^{\mathrm{d}} \\
/ & \text { insulinemia }^{\mathrm{d}}\end{array}$ & $\begin{array}{l}-0.5055 \\
+0.5604 \\
+0.5714 \\
-0.7912^{d} \\
-0.4176\end{array}$ & $\begin{array}{r}-0.5367^{\mathrm{a}} \\
-0.2803 \\
+0.7205^{\mathrm{d}} \\
-0.7109^{\mathrm{d}} \\
-0.5249^{\mathrm{a}}\end{array}$ \\
\hline $\begin{array}{l}\text { SHR-F: } \\
\text { Tergu } 12 \\
\text { obese }\end{array}$ & & $\begin{array}{c}\text { glycemia } \\
\text { insulin binding } \\
\text { glycemia }\end{array}$ & 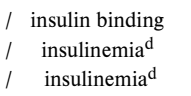 & $\begin{array}{l}-0.5664^{\mathrm{a}} \\
-0.8757^{\mathrm{d}} \\
+0.6935^{\mathrm{c}}\end{array}$ & $\begin{array}{r}-0.4988^{\mathrm{a}} \\
-0.5869^{\mathrm{b}} \\
+0.2653\end{array}$ \\
\hline
\end{tabular}

Table 10. At the left: the parameters which were submitted to correlation computation and the significance of the long term terguride treatment.At the right: cor relation coefficients and their statistical significance.

Abbreviations: Control - control animals, Tergu -animals under the long lasting terguride treAbbreviations: Control - control animals, Tergu -animals under the
atment. The other abbreviations are the same as in Table 1 and 2.
When we are looking for the proper reason of the terguride effect on missing of some correlations and/or appearance of new correlation, the effect of this drug on the individual parameters cannot be overlooked (see Table 10). It is apparent that every change in the significance of correlations is accompanied by the statistically significant changes of appertaining parameters which are used in correlation computation. But exception can be found.Thus, correlation between plasma triglycerides and glycemia attained in control SHR/N-cp lean females statistical significance but under the terguride treatment the significance is missing.This exception suggests that the effect of terguride on correlation is imaginable without effect the drug on parameters which are used for computation of the correlation.

\section{Acknowledgement}

This paper was supported by Internal Grant Agency of Ministry of Health of the Czech Republic No 3684-3. The authors wish to thank Carl T. Hansen, Animal Genetics Division, National Institute of Health, Bethesda, USA, for providing the genetically hypertensive rats of Koletsky type.

\section{References}

1. Golda V, Petr R. Dopaminergic mechanism and genetic factor in blood pressure regulation. Sb Ved Pr Lek Fak Karlovy University Hradec Králové 1982;25:419-27.

2. Golda V, Cvak L. Terguride but not bromocriptine alleviated glucose tolerance abnormalities and hyperlipemia in obese and lean genetically hypertensive Koletsky rats. Physiol Res 1994;43:299-305.

3. Golda V, Cvak L. Ambivalent effect of terguride on glucose tolerance. Physiol Res 1995;44:14P.

4. Golda V, Hilgertová J. Multiple regression analysis of parameters of lipide and glycide metabolism in obese and lean genetically hypertensive Koletsky rats under long lasting terguride treatment. ACTA MED (Hradec Králové) 1996;39:141-8.

5. Hilgertová J, Kümmel L, Hovorka R, Golda V. Decreased insulin binding and internalization in hepatocytes and erythrocytes of SHR Koletsky rats depend on the presence of "f" gene and on sex. Metabolic characteristics of hepatocytes from obese rats. In: Klimeš I, Howard VB, Kahn CR, eds. Insulin and the cell membrane. New York:Harwood Academic Publishers, 1990:81-92.

6. Koletsky S. Pathologic findings and laboratory data in a new strain of hypertensive rats. Am J Pathol 1975;80:129-40.

Submitted December 1997.

Accepted January 1998.

Doc. MUDr. PhDr. Věroslav Golda, CSc., Institute of Experimental Neurosurgery, Charles University, Faculty of Medicine and Teaching Hospital, 50005 Hradec Králové, Czech Republic. 